\title{
Analisis Prevalensi dan Terapi Pada Pada Pasien Diabetes dan Hipertensi Yang Menjalani Hemodialisis dengan Co-Infeksi Hepatitis C di Rumah Sakit Islam Cempaka Putih Jakarta
}

\author{
Diana Laila Rahmatillah *, Gian Fisoma K \\ Fakultas Farmasi, Universitas 17 Agustus 1945 Jakarta \\ *Email korespondensi : dianalailaramatillah@gmail.com \\ (Submit 15/03/2019, Revisi 05/09/2019, Diterima 20/12/2019)
}

\begin{abstract}
Abstrak
Dari profil kesehatan Indonesia tahun 2008 yang diterbitkan Kemenkes menunjukkan angka kasus hepatitis C sebanyak 7234 kasus di tahun 2008 dimana hemodialisis merupakan faktor terbanyak. Penularan itu kemungkinan disebabkan oleh penggunaan dialyzer reuse, transfusi darah, serta praktek pengendalian infeksi yang tidak sesuai standar di ruang hemodialisis. Artikel ini bertujuan untuk mengetahui prevalensi dan terapi Hepatitis C pada pasien diabetes dan hipertensi yang menjalani hemodialisis dengan co-infeksi Hepatitis C di Rumah Sakit Islam Cempaka Putih Jakarta. Cohort prospektif dengan design universal sampling. Pengambilan data berlangsung selama 3 bulan. Data dianalisis menggunakan program Statistical Package for Social Sciences (SPSS ${ }^{\circledR} 22$ ) kemudian disajikan dalam bentuk narasi, tabular maupun diagram. Total populasi sampel adalah 172 dimana 60 diantaranya diketahui terinfeksi hepatitis C. Berdasarkan jenis kelamin, perempuan lebih banyak terinfeksi hepatitis $\mathrm{C}$ di bandingkan laki-laki yaitu $60 \%$ pada perempuan dan $40 \%$ pada laki-laki. Sebanyak 26 . $6 \%$ pasien yang menjalani hemodialsis yang terinfeksi hepatitis C adalah pasien hipertensi sedangkan $31.6 \%$ diantaranya adalah pasien diabetes, namun $41.6 \%$ diantaranya adalah pasien hipertensi dengan diabetes komplikasi. Hepatitis lebih banyak ditemukan pada perempuan dan Ribavirin merupakan terapi Hepatitis $\mathrm{C}$ yang ditemukan pada semua pasien yang menjalani hemodialisis dengan komplikasi hepatitis C di Rumah Sakit Islam Cempaka Putih Jakarta.
\end{abstract}

Kata kunci: Hepatitis C, diabetes, hipertensi, ribavirin, hemodialisis

\section{Outline}

- Pendahuluan

- Metode

- Hasil dan Pembahasan

- Kesimpulan

- Daftar Pustaka 


\section{Pendahuluan}

Hepatitis C merupakan penyakit infeksi yang dapat ditemukan di seluruh dunia, baik di negara maju maupun di negara berkembang. Sekitar $90-95 \%$ dari seluruh hepatitis pasca transfusi disebabkan oleh infeksi virus hepatitis $\mathrm{C}$, dimana sebagian besar diantaranya cenderung tidak terdeteksi dini ${ }^{1,2}$.

Dari profil kesehatan Indonesia tahun 2008 yang diterbitkan Kemenkes menunjukkan angka kasus hepatitis $C$ sebanyak 7234 kasus di tahun 20082. Dari jumlah itu kelompok umur 20-29 tahun merupakan kelompok dengan jumlah kasus terbanyak sejumlah 2505 kasus $^{2}$. Dari Riset Kesehatan Daerah berbasis populasi tahun 2007 yang dilakukan oleh Kemenkes dengan melibatkan 30,000 sampel rumah tangga menunjukkan bahwa angka anti HCV positive adalah $0,8 \%$ dengan populasi tertinggi pada kelompok umur 55-59 tahun sebesar $2,12 \%^{2}$. Hemodialisis dikenal sebagai salah satu rute penyebaran infeksi hepatitis $\mathrm{C}$ sehingga pasien CKD yang menjalani hemodialisis kronik merupakan salah satu kelompok pasien yang memiliki resiko tertinggi terkena HCV².

Analisis penggunaan obat pada pasien hemodialis yang terinfeksi hepatitis $\mathrm{C}$ bertujuan untuk menjamin penggunaan obat yang rasional pada pasien. Penggunaan obat yang rasional sangat penting untuk meningkatkan keberhasilan terapi. Apabila penderita hepatitis $\mathrm{C}$ tidak diterapi dapat menyebabkan terjadinya komplikasi yang dapat memperburuk keadaan penderita. Analisis penggunaan obat merupakan proses jaminan mutu resmi dan terstruktur yang dilaksanakan terus menerus, yang ditujukan untuk menjamin obat yang tepat, aman dan efektif ${ }^{3}$.

Banyaknya jumlah penderita hepatitis $C$ pada pasien hemodialisis serta banyaknya kejadian resiko pemilihan obat untuk terapinya sehingga penelitian ini dilakukan untuk mengetahui gambaran dan mengevaluasi kejadian ketidaktepatan pemilihan obat untuk terapi penyakit hepatitis $\mathrm{C}$ pada pasien hemodialisis ini.

\section{Metode}

Penelitian ini adalah penelitian prospektif longitudinal, dengan desain case control, dimana analisis penyakit dan penggunaan obat diidentifikasi pada saat ini pada semua pasien diabetes dan hipertensi yang menjalani hemodialisis yang terinfeksi hepatitis $C$ dan tidak terinfeksi Hepatitis C di Instalasi hemodialisis Rumah Sakit Islam Jakarta.

\section{Sumber Data}

Data diperoleh dari rekam medik semua pasien yang menjalani hemodialisis dan perawat di instalasi hemodialisis Rumah Sakit Islam Jakarta. Penggambilan data menggunakan universal sampling yaitu berapapun pasien hipertensi dan diabetes yang menjalani hemodialisis yang terinfeksi hepatitis $C$ ataupun tidak terinfeksi hepatitis $C$ yang mendapatkan obat di Instalasi hemodialisis di Rumah Sakit Islam Jakarta dalam kurang lebih 3 bulan yakni mulai tanggal 1 Februari hingga 30 April 2016 bisa memenuhi data. 
Kriteria Inklusi dan Ekslusi

Kriteria ekslusi adalah semua pasien diabetes dan hipertensi yang sudah menjalani hemodialisis pasien usia > 18 tahun, pasien hepatitis B, Pasien HIVIAIDS, Pasien cancer, dan pasien hamil di Instalasi hemodialisis hemodialisis di Rumah Sakit Islam Jakarta.

\section{Metode Pengumpulan Data}

Data yang dikumpulkan dalam penelitian yaitu data sekunder yang merupakan data yang diperoleh berdasarkan hasil pengamatan. Data tersebut berisi tentang identitas pasien beserta informasi-informasi lain yang dipindahkan dari status pasien. Data yang dikumpulkan dipindahkan ke lembar pengumpulan data lalu dianalisis menggunakan program Statistical Package for Social Sciences (SPSS ${ }^{\circledR} 22$ ) kemudian disajikan dalam bentuk narasi, tabular maupun diagram.

\section{Analisa Data}

Data dianalisis secara deskriptif dan prospektif dengan perhitungan dan persentase disajikan dalam bentuk tabulasi dan diagram dengan statistik untuk menghitung significanci. Menggunakan Statistical Package for Social Sciences (SPSS ${ }^{\circledR} 22$ ).

\section{Hasil dan Pembahasan}

Dari hasil penelitian terdapat 172 pasien yang menjalani hemodialisis hanya 60 pasien yang memenuhi kriteria inklusi yang diambil pada periode 1 Februari - 30 April 2016.

\section{Anti HCV Positif}

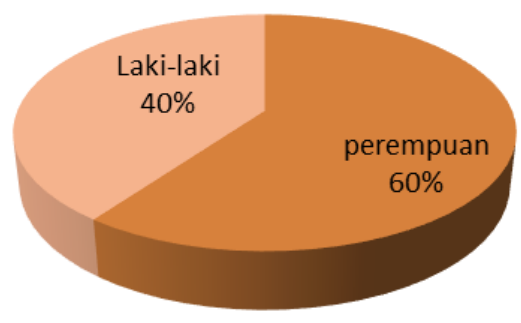

Gambar 1. Sosiodemografi Berdasarkan Jenis Kelamin dan Jumlah Pasien Hipertensi dan Diabetes Yang Terinfeksi Hepatitis C yang Menjalani Hemodialisis.

Berdasarkan Gambar 1 di atas didapatkan bahwa pasien hemodialsis hipertensi dan diabetes yang terinfeksi hepatitis $\mathrm{C}$ berjenis kelamin perempuan lebih banyak dibandingkan laki-laki dimana jumlah pasien perempuan sebanyak 36 pasien dengan presentase $60 \%$ dan jumlah pasien laki-laki sebanyak 24 pasien dengan presentase $40 \%$.

Jenis kelamin mempunyai hubungan terhadap suatu masalah hemodialisis Laju Filtrasi Glomerulus (LFG) dianggap sebagai ukuran terbaik dari ginjal, LFG normal keseluruhan fungsi bervariasi sesuai dengan usia pasien, jenis kelamin dan ukuran tubuh. Pada orang dewasa muda, LFG normal adalah kurang lebih 120-130 ml/menit/1,73 m dan 
dengan menurun umur 14-17 Tingkat LFG di bawah $60 \mathrm{ml} / \mathrm{menit} / 1,73 \mathrm{~m}$ merupakan kehilangan satu setengah atau lebih dari tingkat dewasa normal fungsi ginjal. Riwayat transfusi darah dan penggunaan dialyzer reuse akan mengakibatkan penularan infeksi hepatitis $C$ dan pada pasien hemodialisis kronik pada wanita lebih rentan terkena hepatitis C. Riset menunujukkan jenis kelamin perempuan memiliki kaitan terhadap penyakit diabetes dan hipertensi yang lebih banyak dibandingkan laki-laki.

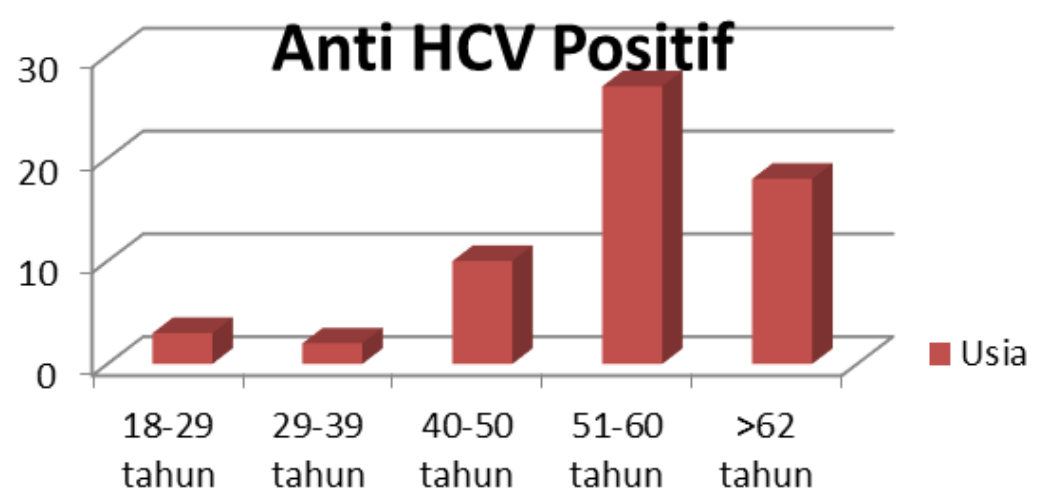

Gambar 2. Distribusi Frekuensi dan Persentase Usia dan jumlah pasien Berdasarkan Karakteristik Pasien Hipertensi dan Diabetes dengan Hepatitis C yang Menjalani Hemodialisis

Berdasarkan Gambar 2 diatas di dapatkan bahwa pasien yang menjalani hemodialisis berdasarkan pengelompokan usia yaitu 18-29 tahun terdapat 3 pasien dengan presentase $5 \%$ pasien diabetes yang positif HCV presentase terkecil dan jarang sekali di temukan pasien yang menjalani hemodialisis di usia tersebut.

Pada diagram urutan kedua usia 29-39 tahun terdapat 2 pasien hemodialisis diabetes dan hipertensi dengan presentase $3,3 \%$ tersebut positif HCV. Pada tabel urutan ketiga pada usia 40-50 tahun terdapat 10 pasien dengan presentase $16,6 \%$ yang terinfeksi hepatitis C. Pada tabel keempat usia 51-60 tahun terdapat 27 pasien dengan presentase $45 \%$ yang terinfeksi hepatitis $C$, dan pada tabel terakhir usia diatas 62 tahun terdapat 18 pasien dengan presentase $30 \%$ yang terinfeksi hepatitis $\mathrm{C}$. Usia rerata pasien hemodialisis kronik adalah 60 tahun dengan rentang usia dari 19 tahun sampai 65 tahun. Frekuensi terbanyak pasien hemodialisis kronik terdapat pada rentang usia 51-61 tahun. Semakin lama menjalani hemodialisis maka tidak menutup kemungkinan pasien hemodialisis terinfeksi hepatitis $\mathrm{C}$ dan faktor lanjut usia tersebut. Pada usia diatas 62 tahun didapatkan dengan jumlah terbanyak urutan kedua dari pasien usia 5160 tahun, usia berpengaruh terhadap resiko mudah tertularnya infeksi hepatitis C. Pada penelitian ini didapatkan hasil bahwa umumnya penderita sirosis hati berusia diatas 51 tahun, dengan rerata usia 56 tahun.

Berdasarkan Gambar 3 didapatkan bahwa pasien hipertensi yang sedang menjalani hemodialisis dan positif terinfeksi hepatitis $C$ sebanyak 16 pasien dengan presentase $26,6 \%$ dari 60 pasien positif hepatitis $C$ dari 172 pasien yang menjalani hemodialisis. Jumlah presentase ini lebih sedikit di bandingkan dengan pasien diabetes yang terinfeksi hepatitis $\mathrm{C}$. Hipertensi umum terjadi dan sulit terkontrol dengan baik pada pasien dengan hemodialisis kronis ${ }^{4}$. 


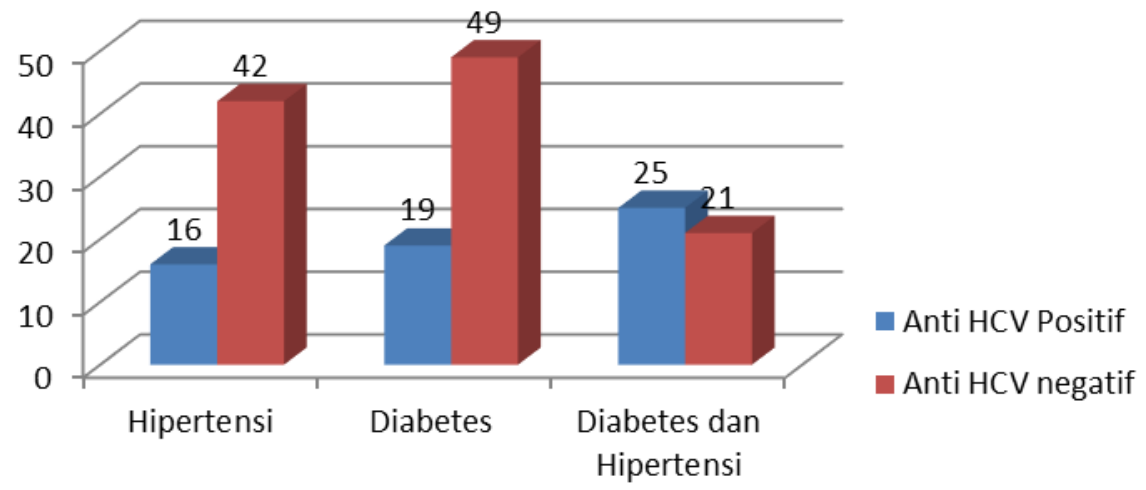

Gambar 3. Distribusi Frekuensi dan Pasien Hipertensi, Diabetes dan Hipertensi dengan Diabetes Berdasarkan jumlah Pasien Hemodialisis yang Positif HCV atau Negatif HCV

Pada pasien hipertensi yang negatif hepatitis $\mathrm{C}$ sebanyak 42 pasien dengan presentasi $37,5 \%$ dari 60 pasien positif hepatitis $C$ dari 172 pasien yang menjalani hemodialisis. Pada pasien Diabetes terdapat 19 pasien hemodialisis positif hepatitis $C$ dengan presentase $31,6 \%$ dari 60 pasien positif hepatitis $C$ dan 49 pasien negatif hepatitis $C$ dengan presentase $43,7 \%$ dari 112 pasien hepatitis $C$ negatif.

Pasien diabetes yang terinfeksi hepatitis $\mathrm{C}$ merupakan jumlah yang paling banyak karena diabetes merupakan bagian dari sindrom metabolik yang dicirikan oleh sekelompok abnormalitas biokimia berupa hiperinsulinemia, hiperglikemia, dislipidemia, dan hipertensi ${ }^{5}$.

Pada pasien hipertensi dan diabetes yang terinfeksi hepatitis $\mathrm{C}$ didapatkan 25 pasien dengan presentase $41,6 \%$ dari 60 pasien yang positif hepatitis C. dan 21 pasien hipertensi dan diabetes yang negative hepatitis $C$ dengan presentase $18,7 \%$ dari 112 pada pasien yang negative hepatitis $C$ yang menjalani hemodialisis. Rerata jumlah paling banyak didapatkan pada pasien hipertensi dan diabetes dengan jumlah 25 pasien dari 60 pasien positif hepatitis $\mathrm{C}$, keduanya merupakan komplikasi yang dapat memperburuk kondisi pasien hemodialisis.

Tabel 1. Hubungan Antara Usia Dengan Jumlah Pasien Hemodialisis yang Terinfeksi Hepatitis C

\begin{tabular}{|c|c|c|c|}
\hline Usia & $\mathrm{N}(60)$ & $\%$ & P value \\
\hline 18-29 tahun & 3 & 5 & 0.001 \\
\hline 29-39 tahun & 2 & 3,3 & \\
\hline 40-50 tahun & 10 & 16,6 & \\
\hline 51-61 tahun & 27 & 45 & \\
\hline >62 tahun & 18 & 30 & \\
Total & 60 & 100 & \\
\hline
\end{tabular}

Berdasarkan hasil uji statistik di atas (Tabel 1) dapat disimpulkan bahwa ada hubungan antara usia dengan jumlah pasien hemodialisis yang terinfeksi hepatitis $\mathrm{C}$, data yang didapatkan dengan uji chi square $p$ value* 0.001 menunjukkan signifikansi. Pada kriteria usia pasien hemodialisis di Rumah Sakit Islam Jakarta, jumlah pasien hemodialisis 
yang terinfeksi hepatitis $C$ yang terbanyak adalah pada usia 51-61 tahun, diikuti oleh usia >62 tahun sedangkan jumlah terkecil pada usia 18-29 yaitu sebanyak 3 pasien.

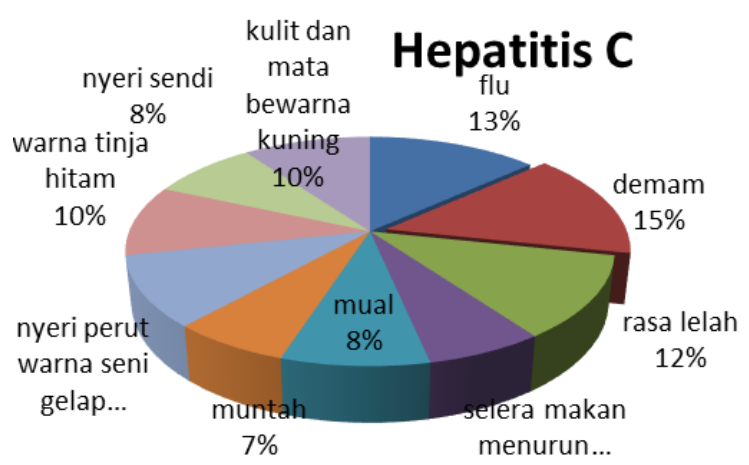

Gambar 4. Jumlah Atau Presentase Gejala Yang Muncul Pada Hepatitis C Pada Pasien Diabetes, Hipertensi dan Diabetes Dengan Hipertensi Yang Menjalani Hemodialisis.

Gambar 4 menjelaskan gejala yang paling banyak muncul pada hepatitis $C$ yaitu demam sebanyak $15 \%$, flu $13 \%$ dan rasa lelah sebanyak $12 \%$, kulit dan mata bewarna kuning $10 \%$, nyeri sendi $8 \%$, warna tinja hitam $10 \%$, nyeri perut warna seni gelap $10 \%$, muntah $7 \%$, mual $8 \%$, dan selera makan menurun sebanyak $7 \%$. Banyak pasien yang awalnya tidak menunjukkan gejala, atau hanya menderita penyakit ringan seperti flu, pasien mengira hanya sakit demam biasa. Pada beberapa kasus, air seni dapat menjadi gelap, kulit dan matanya menjadi kuning (jaundice).

Tabel 2. Distribusi Karakteristik Obat Yang Diberikan Pada Pasien Diabetes dan Hipertensi Yang Menjalani Hemodialisis Yang Terinfeksi Hepatitis C

\begin{tabular}{|c|c|c|c|c|}
\hline Terapi & Hipertensi & Diabetes & $\begin{array}{c}\text { Hipertensi dan } \\
\text { Diabetes }\end{array}$ & Total \\
\hline Losartan & 16 & 0 & 0 & 16 \\
\hline Ribavirin & 0 & 19 & 0 & 19 \\
\hline $\begin{array}{c}\text { Losartan dan } \\
\text { Ribavirin }\end{array}$ & 0 & 0 & 25 & 25 \\
\hline Total & 16 & 19 & 25 & 60 \\
\hline
\end{tabular}

Dari Tabel 2 dapat dilihat bahwa pasien yang mendapatkan obat losartan adalah pasien hipertensi yang menjalani hemodialisis yang terinfeksi hepatitis C yaitu sebanyak 16 pasien dengan presentase $26,6 \%$. Losartan merupakan salah satu Angiotensin Receptor Blocker (ARB) yang diindikasikan untuk hipertensi ${ }^{6}$. Selain itu, losartan juga dapat memperlambat progresivitas nefropati diabetik dan kelainan ginjal lain pada pasien diabetes melitus tipe II, hipertensi, dan mikroalbuminuria ( $>30 \mathrm{mg} / \mathrm{hari}$ ) atau proteinuria (> $900 \mathrm{mg} / \mathrm{hari}^{7}$.

Pada Tabel 2 yang mendapatkan obat ribavirin sebanyak 19 pasien dengan presentase $31,6 \%$ adalah pasien hemodialisis hipertensi yang terinfeksi hepatitis C. Diketahui banyak diantara pasien dengan hepatitis $\mathrm{C}$ membaik dengan menggunakan terapi antiviral $^{8}$. Obat antiviral yang paling umum adalah kombinasi dari pegylated interferon alfa dan ribavirin 8 . 


\section{Kesimpulan}

Berdasarkan jenis kelamin maka perempuan lebih banyak terinfeksi hepatitis $\mathrm{C}$ di bandingkan laki-laki yakni $60 \%$ pada perempuan dan $40 \%$ pada laki-laki dengan jumlah 60 populasi sampel. Pasien hemodialisis di Rumah Sakit Islam Cempaka Putih Jakarta banyak yang terinfeksi hepatitis $C$. Namun, pengobatan hepatitis $C$ dengan antiretroviral Ribavirin sudah ditemukan pada sebagian pasien hemodialisis yang terinfeksi hepatitis C di Rumah Sakit Islam Cempaka Putih Jakarta.

\section{Daftar Pustaka}

1. Kelly DA. Hepatitis C infection after blood product transfusion. Arch Dis Child. 1996;75(5):363-365. doi:10.1136/adc.75.5.363

2. Pantazis KD, Elefsiniotis IS, Brokalaki H. New Data concerning the Epidemiology of Hepatitis B Virus Infection in Greece. Gastroenterol Res Pract. 2008;2008:1-4. doi:10.1155/2008/580341

3. Hestry Angraini. Ramatillah, Diana Laila Widayati. Eval Pengguna Obat Antihipertensi Pada Pasien Hemodialisa Yang Telah Meninggal Dari Tahun 20102015 di Rumah Sakit Islam Jakarta Cempaka Putih. 2015;1(1):1-7.

4. Diseases K. American Journal of Kidney Diseases. Vol 36.; 2000. doi:10.1053/j.ajkd.2003.10.012

5. Fallahi $P$, Ferrari SM, Colaci $M$, et al. Hepatitis $C$ virus infection and type 2 diabetes. Clin Ter. 2013;164(SUPPL.5):586-600. doi:10.7417/CT.2013.1620

6. National Kidney Foundation. KDIGO 2012 Clinical Practice Guideline for the Evaluation and Management of Chronic Kidney Disease KDIGO 2012 Clinical Practice Guideline for the Evaluation and Management of Chronic Kidney Disease. Kidney Int. 2013;3(1):Supplement. doi:10.1038/kisup.2012.76

7. Ripley, Hirsch. Fifteen years of losartan: What have we learned about losartan that can benefit chronic kidney disease patients? Int J Nephrol Renovasc Dis. 2010;3:93-98.

http://www.embase.com/search/results?subaction=viewrecord\&from=export\&id=L35 9341078\%0Ahttp://www.dovepress.com/getfile.php?fileID=6619\%0Ahttp://sfx.library .uu.nl/utrecht?sid=EMBASE\&issn=11787058\&id=doi:\&atitle=Fifteen+years+of+losar $\tan \% 3 A+$ What +have+we+learned.

8. Thomas DL, Leoutsakas D, Zabransky T, Kumar MS. Hepatitis C in HIV-infected individuals: Cure and control, right now. J Int AIDS Soc. 2011;14(1):22. doi:10.1186/1758-2652-14-22 